\title{
Pituitary Homeobox 2
}

National Cancer Institute

\section{Source}

National Cancer Institute. Pituitary Homeobox 2. NCI Thesaurus. Code C75893.

Pituitary homeobox 2 (317 aa, $\sim 35 \mathrm{kDa}$ ) is encoded by the human PITX2 gene. This protein is involved in transcriptional regulation during pancreatic development. 